\title{
LEADING PRIORITIES FOR DEVELOPMENT OF THE HIGH TECHNOLOGIES MARKET
}

\author{
Eugenijus Chlivickas¹, Neringa Petrauskaitė², Nikolaj Ambrusevič̌3 \\ Vilnius Gediminas Technical University, Saulètekio al. 11, 10223 Vilnius, Lithuania \\ E-mails: eugenijus.chlivickas@vgtu.lt; ${ }^{2}$ neringa.petrauskaite@vgtu.lt; \\ 3nikolaj.ambrusevic@vgtu.lt \\ Received 20 March 2008; accepted 5 September 2009
}

\begin{abstract}
High technologies development has strategic importance to improving regional EU and national economies effectiveness and assuring a country's competitiveness. This is especially a key priority for small countries that do not have many natural and material resources, as well as labour force. Therefore, in the article the specifics of high technologies development that derives from exceptional high technologies features is analysed. These specific features of high technologies influence the rise of specific characteristics of high technologies market. Thus, the article aims to set leading priorities for a successful development of high technologies business in Lithuania.

Development of the high technologies business depends first of all on development of the high technologies market. The success of developing high technologies depends on implementation of the 'triple helix' model covering integration of the public and private sector as well as science. The most successful 'triple helix' model for high technologies development is the one where the highest degree of cooperation between authorities, industry and academic public is indicated. Therefore the article establishes the implementation of the 'triple helix' as a leading priority for high technologies development in Lithuania.
\end{abstract}

Keywords: high technologies, development of the high technologies business, characteristics of high technologies, triple helix model, Lithuania.

\section{Introduction}

Studies of such scientists as Agmon, Messica (2006), Rausch (1998), Melnikas (2004), Ghazinoory et al. (2009), Bielskis et al. (2009), Snitka (2002) and others as well as strategically significant documents of national and international organizations tend to focus on the importance of high technologies in the period of intensive economic globalization because high technologies development is a strategically essential area promoting efficiency of a regional and national economy and ensuring a competitive edge of a region and a country. This is quite relevant to the EU and particularly relevant to small countries which do not hold substantial natural, material or labour resources. Countries developing high technology products not only gain a technological advantage, create marketable products for export, but also promote the rapid growth of the Gross Domestic Product as they create the highest value added. Therefore, it is very important to strive for the rapid high technology business development.

The first step to prompt expansion of innovations and also high technologies in the EU was the Green Paper on Innovation of 1995 which according to Rossi (2005) was followed by the First Action Plan for Innovation in Europe. "The fundamental progress was made when implementing the aims of the Lisbon Strategy (2000) in 2002 the Council of Europe in Barcelona defined a target for 2010 for the scientific research and experimental development (R\&D) to constitute 3 percent of Europe's GDP and investments into the R\&D from the private sector to account for two thirds of the overall investment into the R\&D" (Rossi 2005). Understanding the role of innovations for the development of economy, the European Union both reforms its approach to an active and independent position of the Member States regarding innovations, and implements relevant mechanisms on the EU level oriented towards promotion of the innovation culture, creation of the framework conducive to innovations and orientation of science towards innovations in spheres of industry and services. Lithuania as a member of the EU is also seeking those goals and developing a system encompassing strategic plans, organizational structures and processes to assist promotion of high technologies.

In the last few years the development of high technologies in Lithuania considerably lags behind in comparison with the EU level. According to the data provided 
by the Department of Statistics to the Government of the Republic of Lithuania in 2007 in Lithuania 419 companies operated in this area, which is 0.3 percent of the companies in total and the number of employees in those companies accounted for 0.8 percent of all employees in Lithuania. The program for development of high technologies by 2013 indicates that currently a share of the GDP generated by production of high technologies in Lithuania is less than 6 percent which is half as much in comparison with the EU average: Lithuania exports about three times less than the EU average. Based on the Eurostat data of 2006 Lithuania in terms of this indication is ranked twenty-third among the EU countries (4.65\%) and from Malta which is the leader in this respect (54.61\%) it lags behind almost twelve times, from Luxembourg which is the runner-up $(40.66 \%)$ it lags behind nine times and six times from Ireland (29.01\%). Meanwhile the export share of high technologies in the USA and Japan in the total export of the country constitutes 26.13 percent and 20.04 percent accordingly.

Moreover, Lithuania considerably falls behind in implementing the EU goal by 2010 to achieve that the R\&D would constitute 3\% of Europe's GDP and investments into the R\&D from the private sector would be two thirds of the overall investment into the R\&D. According to the data provided by the Department of Statistics to the Government of the Republic of Lithuania in 2007 the funding allocated for the R\&D constituted only 0.17 percent of the Gross Domestic Product of Lithuania which is nearly eighteen times less than the target. The majority of the R\&D (about 48\%) was financed from the state funds. Meanwhile, the financing share of business companies was merely 24 percent of all expenses for the R\&D. So far this indication is almost three times lower than the target to be reached by 2010 .

All those numbers indicate that Lithuania considerably lags behind both the EU average and also the majority of countries in the area of development of high technologies. They also imply that the current significant gap between indications of Lithuania in the area of high technologies as well as the R\&D and the EU aims will not be eliminated by 2010 and the EU targets for the area of high technologies in Lithuania will not be reached. However, as it is evidenced that the expansion of high technologies and high technologies business is not as fast as desired, therefore it is quite complicated. Thus, the objective of the present research is to establish strategic priorities for a successful development of high technology business in Lithuania. In order to achieve this aim, at first it is necessary to define the concept and characteristics of high technologies, due to which the business in question is characterized by specific features directly affecting its expansion. Furthermore, we should distinguish the key elements in the system of the business expansion as well as identify priorities of their successful interface pursuing the expansion of high technologies business in Lithuania upon analysing the interface of elements in the expansion system of high technologies in Lithuania, which are the objectives of the present research in achieving the main aim. To reach the set aim, an analysis of scientific literature and qualitative analysis of the expansion of high technologies in Lithuania as well as systems ensuring the expansion in question have been conducted.

\section{Defining high technologies}

In the opinion of Aydalot, Keeble (1988) and Goss, Vozikis (1994) there has not been a uniform concept as to what high technologies are. According to the British Business daily of 1987 the term of high technologies was fashionable and used to be attributed to a number of products and markets (Meldrum 1995), thus it is quite likely that even the products which did not have features of high technology products were referred to as such. Furthermore, as Walsh (2003) notes the notion of high technologies was changing in time, since it is not constant due to its content: what used to be understood as high technologies after a period of time can no longer be attributed to high technologies, and some technologies cannot be regarded as high technologies because what yesterday were high technologies, today may be usual and widely spread technologies. This is to say that the basis for the characteristics defining high technologies should be dynamics.

For that reason we should not follow the attempts of Gardner et al. (2000), McGuckin et al. (1992) as well as McNally (1995) to define high technologies by identifying specific sectors. Yet attributing products which have certain features to high technologies and classification of such technologies into sectors is a logical process enabling to structure the knowledge in the area of high technologies and simplify the concept of high technologies. Unfortunately, nowadays around the globe a number of classifications of high technologies is used (e.g. in America the most frequently used classifications of high technologies sectors are U.S. Standard Industrial Classification, American Electronics Association, Regional Financial Associates, One Source Information Services Inc., U.S. Bureau of Labor Statistics, The North American Industrial Classification System, whereas in Europe the high technologies sector is 
usually discussed referring to The Hamburg Institute of International Economics, Eurostat, The Organisation for Economic Cooperation and Development and other clasificators). In Lithuania the high technologies sectors are traditionally information technologies, telecommunications, biotechnology and pharmaceutical sector, laser technologies, electronics, mechatronics and nanotechnologies (Žalioji knyga [Green paper] 2006), thus understanding of high technologies becomes even more complicated.

Clarke, Stough (2001) maintain that objective and subjective definitions of high technologies are still possible. In their opinion with subjective definitions, the researcher develops a definition based on personal criteria, [...] objective definitions can be used for multiple regions and as more use of the definition, it gains credibility. Thus, it may be concluded that upon defining high technologies by such features which would be meaningful in the global market, we could have objective characteristics of high technologies and on their basis identify products satisfying such characteristics.

According to the scientists such characteristics should describe a developed product, therefore Rexroad (1983) defines high technologies as the newest, most innovative and modern products at a given period, furthermore according to Allen (1992), Riggs (1983), Shanklin, Ryans (1984) first of all it should be noted that the products in question (goods and services) are inseparable from application of science and technologies. Riggs (1983), Ryans, Shanklin (1984), Rosenau (1988), Davidow (1986), MacInnis, Helslop (1990), Goldman (1982) identify short life cycle in the market as another specific characteristics of high technologies. In the opinion of McIntyre (1988) also supported by Sahadev, Jayachandran (2004), Meldrum (1995), indispensability of associated infrastructure should also be added to the list of specific characteristics of high technologies. The nature of high technology implies that there is unlikely to be an established external infrastructure which will make it easy to commercialize high technology products (Meldrum 1995) (Table 1).

Other scientists including Lawrance, Miller (1996), Kask, Sieber (2002), Chabot (2008) note that all classifications of high technologies markets can be divided into two groups: classifications of high technologies based on resources and generated produce, i.e. where in addition to analysis of the product features, the characteristics of high technologies are distinguished, which encourages to consider the structure and characteristics of labour force as well as other input necessary to manufacture the product.
Table 1. Characteristics of high technologies

\begin{tabular}{|c|c|}
\hline $\begin{array}{l}\text { Characteristics of } \\
\text { high technologies }\end{array}$ & Author, year \\
\hline $\begin{array}{l}\text { Short product life } \\
\text { cycle }\end{array}$ & $\begin{array}{l}\text { H. E. Riggs 1983; W. L. Shanklin, } \\
\text { J. K. Ryans 1984; M. D. Rosenau } \\
\text { 1988; W. H. Davidow 1986; } \\
\text { M. MacInnis, L. A. Helslop 1990; } \\
\text { A. Goldman 1982. }\end{array}$ \\
\hline $\begin{array}{l}\text { Inseparable from } \\
\text { development of } \\
\text { technologies }\end{array}$ & $\begin{array}{l}\text { H. E. Riggs 1983; J. C. Allen 1992; } \\
\text { S. Sahadev, S. Jayachandran 2004; } \\
\text { W. L. Shanklin, J. K. Ryans } 1984 .\end{array}$ \\
\hline $\begin{array}{l}\text { Inseparable from } \\
\text { science }\end{array}$ & $\begin{array}{l}\text { H. E. Riggs 1983; J. C. Allen 1992; } \\
\text { W. L. Shanklin, J. K. Ryans } 1984 .\end{array}$ \\
\hline $\begin{array}{l}\text { Inseparable from } \\
\text { the existing } \\
\text { infrastructure }\end{array}$ & $\begin{array}{l}\text { S. H. McIntyre 1988; S. Sahadev, } \\
\text { S. Jayachandran 2004; } \\
\text { M. J. Meldrum } 1995 .\end{array}$ \\
\hline
\end{tabular}

Source: compiled by the authors

\section{Specific characteristics of high technologies business}

Due to dependence on rapidly changing technologies, technological environment and a short product life cycle, the market of high technologies in the opinion of Riggs (1983), Meldrum (1995), Sahadev, Jayachandran (2004), Rosen et al. (1998), is particularly risky. The market is risky primarily because of a set of product attributes: innovativeness, complexity and a short life cycle. High technology products are innovative and complex, which is why it is often difficult for users to realize a service, its value and benefit. In other words, users are not certain about the product, so it is quite difficult to convince them to buy rather expensive high technology goods or services. Furthermore, customers' risk is driven from a lack of experience in applying, maintaining and using the technology, which increase a chance of problems, such as further costs, interruptions to support continuity, unexpected side-effect or quality devices (Meldrum 1995).

Due to that a product may fail in the market and this is what increases the possibility of failure for the firm. Furthermore, high technology products may become technologically obsolete within a short period of time due to a greater possibility of discontinuous change occurring in the product technology domain (Sahadev, Jayachandran 2004). Moreover, the high technologies business is particularly risky because it is complicated to estimate a long-term value of the technology, product or service being developed.

One more significant particularity of the high technologies business is that it is investment consuming. Large 
investments in the sector of high technologies are necessary in case a new technology or a product is being developed, and investments are made into expensive research, technologies, their application, support and training of employees.

Another important characteristic of the high technologies business is a rapidly changing market: technological, economic, social environment and legal regulation, competition in the market as well as consumer needs and expectations and other circumstances.

In addition, due to a high value added created, this market is attractive and in the opinion of Rosen et al. (1998) intense competition in the high technologies market is another feature characteristic of the sector in question.

\section{Triple helix model - key priority for a successful development of high technologies business}

Due to exceptional characteristics of high technologies and specific features of the high technologies sector, development of this business is rather complicated because processes of business promotion, innovation spread and fostering of the technological progress are highly intricate and it is important to know that expansion of high technologies business first of all strongly depends on the development of high technologies. According to Melnikas (2004) it means that promotion of such processes and purposeful management of operations of their participants requires a complex approach.

Therefore, considering the benefit of high technologies to the economic growth of countries, their specific characteristics and features typical of the high technologies market, we may claim that a successful development of high technologies is primarily inseparable from the 'triple helix' model: the academic public - industry government. To put it in other words - for the development of high technologies to be efficient it is necessary to have: the public sector responsible for promotion of high technologies business development which would lower its risk to some extent, the science generating innovative ideas of technologies and the business supporting and implementing such ideas. Such integration would ensure efficient high technologies development and furthermore partially decrease risk and investment associated with the high technologies business.

The model based on cooperation of science institutions, industrial enterprises and authorities is not new. It was introduced almost a hundred years ago and such a model promoting expansion of the high technologies sector was first suggested in the 1920s in the United States of America. It became the basis for developing programs promoting expansion of high technologies from the 1930s to mid-80s when specialised Massachusetts Institute of Technology was established mainly working in the area of developing and implementing innovations.

The 'triple helix' model of high technologies reflects the entirety of multi-faceted relations affecting stages of creation and capitalisation of innovations. The model consists of three main and independent helices indicating processes associated with development of innovations and high technologies in the academic public, state institutions and business sector. One of the aspects of the 'triple helix' model in question is internal communication undergoing in every element of the model irrespective of the processes in other helices. Among key indications we might list horizontal ties among enterprises, establishment of joint strategic associations, creation of common programs of economic or innovation growth of universities. Another important factor is an interface of helices manifesting through the influence of state institutions in fostering development of high technologies by promoting a close cooperation between the academe and business sector: when elements of the authorities ensure an adequate legal and financial basis for intellectual produce, at universities the activities oriented towards development of innovations become more dynamic and a growing number of business enterprises are willing to realize their final produce. The third criterion is shown as a close cooperation of the three helices on a horizontal level, which alleviates the process of generating and realizing new ideas and developing new technologies.

The 'triple helix' model indicates a relationship among the university, industry and authorities as an entirety of overlapping areas reflecting an impact of each element on other spheres. Etzkowitz et al. (2000) and Wessner (1999) analysing expansion of high technologies in different regions of the world distinguished three main configurations of the 'triple helix' model.

The first model reflects a situation, which in the opinion of the authors is characteristic of the former republics of the Soviet Union and some Latin American countries. The areas indicating elements of the industry and academic public exist independently without interacting. The dominant role of an intermediary is played by the authorities being the only element ensuring relations between the sectors. This model represents situation in which the state incorporates industry and academic public, where state owned industries are predominant (Fig. 1 ). 
The second model shows mutual relations of different elements but does not reflect their advantages and influence to generation of new ideas, creation of innovations and expansion of high technologies. In the opinion of the authors this model is characteristic of the United States of America. The model allows to establish relations between different spheres, when each of them plays an independent role in its own area only, but does not express the nature of those relations (Fig. 2).

The continental Europe and countries referred to fastest economic growth showing countries typically have the 'triple helix' model, the elements of which closely cooperate without distinguishing importance of any sphere (Fig. 3).

Researchers Viale and Campodall' Orto (2000) attribute the latter model to the USA, EU and other countries with a close cooperation among separate institutions of science, business and government.

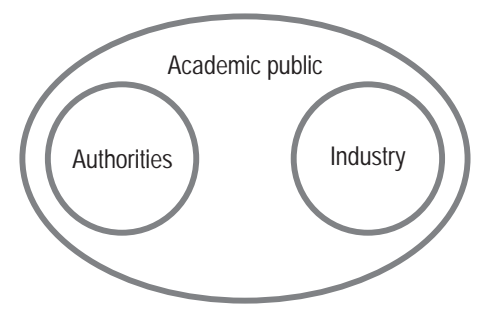

Fig. 1. The 'triple helix' model with one dominating element

Source: Etzkowitz et al. 2000

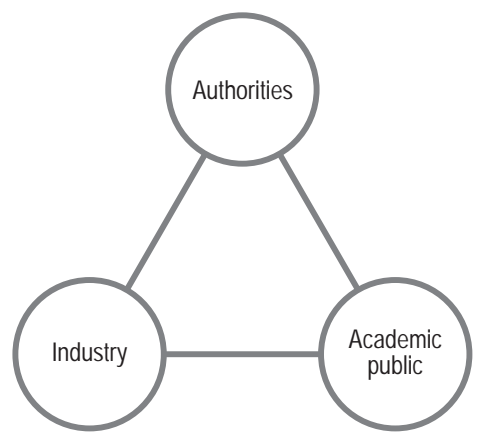

Fig. 2. The 'triple helix' model of mutual relations Source: Etzkowitz et al. 2000

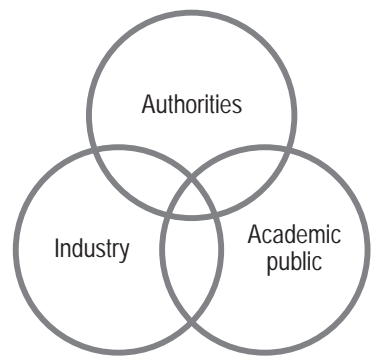

Fig. 3. The 'triple helix' model of overlapping elements Source: Etzkowitz et al. 2000
The application of different configurations of the "triple helix ' model depends not only on determined goals in science and area of research and development, but also on political and socio-economic situation in the country. The first model, in which one sphere dominates the others, is suitable for the countries with strong influence of authorities, where the government sets the priorities in industry development and provides financial tools for it. The tendency is observed in the countries with close type of economy, with strong ideological dominance in socio-economy or during the economic transition from one form to another. In Lithuania this model was in use during being part of Soviet Union and economic transition period in the 90s until in 2001 Lithuania's White Book on Science and Technology was accepted.

The second model of institutional spheres as separate from each other is applied in countries with numerous population and difficult system of institution, such as federation, confederation or commonwealth. In theory it is how the United States of America, Russia, Germany, Great Britain are supposed to work. This model allows to manage investments and to allocate them properly into different spheres of industry and academia. Element of authorities plays the role of meeting point for state, industry and academia interests.

The third model with overlapping spheres shows the highest grade of cooperation between elements. This way of cooperation may be found in practice in countries with stable economic and political environment, foreign trade liberalization and business internationalization. The last configuration of 'triple helix' model allows to solve all problems in innovations implementation in the form of negotiation and transaction.

In order to ensure expansion of the high technologies sector in Lithuania, it is suggested to use the 'triple helix' model of overlapping elements, envisaging a continuous interaction of science institutions creating innovations, the business sector capable of financing realization of ideas and the government regulating that process and at the same time fostering development of high technologies when the business risk is decreased, innovative ideas of the progressive science are generated and their implementation ensured.

\section{Implementing the 'triple helix' model in the high technologies market of Lithuania}

In Lithuania from the very beginning the 'triple helix' model was constructed for the expansion of high technologies and the working group, that developed the conception of Lithuania's White Book on Science and Technology, included representatives from the authorities, industry and science state institutions. 
All the three sectors are involved both into creation of programs for development of high technologies and organization as well as control of their implementation. That is obvious since implementation of the high technologies development is undertaken by the Science and Studies Foundation which at first via competition selects a project that could be prepared by science and education institutions together with business enterprises. Involvement of the three sectors is illustrated by the key principles of the organization of the high technologies development: councils are established for each objective of the program for the high technologies development including scientists, representatives of business organizations, the Ministry of Education, the Ministry of Economy and the Information Society Development Committee under the Government of the Republic of Lithuania, and such councils provide proposals to the Science and Studies Foundation regarding organization of competition for projects (measures) of the program, evaluation of projects and projects worth to be implemented, analyse project implementation reports, monitor implementation of the program, supervise its administration and assess implementation of the program. In addition to the above mentioned institutions, the Knowledge Society Council under the President of Lithuania and the Information Society Development Committee under the Government of the Republic of Lithuania are also to some extent responsible for implementation of the measures of the high technologies development program and expansion of innovations and may provide their recommendations. The Ministry of Finance which manages, the Central Project Management Agency which implements absorption of the EU structural funds, and the Agency for International Science and Technology Development Programmes in Lithuania are also involved, and the organization of the R\&D which is inseparable from the high technologies development is undertaken by the Science Council of Lithuania, the Lithuanian Academy of Sciences, the Lithuanian Catholic Academy of Science, the Lithuanian Universities Rectors' Conference, the Board of Directors of Lithuanian Science Institutes, the Conference of Chairmen of Senates (Councils) of the Lithuanian Universities and Research Institutes and the Lithuanian Scientific Society. The inter-institutional, organizational and hierarchical structure of the said state institutions and their relations are quite complicated and the system of planning, implementation of organization and control of the high technologies development supersaturated with various institutions indicates that the authorities through their wide range of institutions perform a role of the dominating intermediary in this process.
It is equally important to note that in Lithuania the involvement of all the three parties in promotion of development of high technologies is not based on mutual cooperation for the common goal. An independent existence of the industry and academic public and lack of their interaction is evidenced by the fact that in Lithuania the industry gives priority to foreign technologies and innovations mistrusting the local science. Such situation may be explained by the out-ofdate technological basis of scientific centres which is unfit for development of new technologies. Therefore one of the main objectives in fostering cooperation between the science and business sectors is updating of the facilities at science institutions and laboratories. The Ministry of Education and Science has been undertaking such program for a few years already, but the allocated funding is very insignificant. The solution would be creation of equipment centres for common use which could be exploited by a number of universities or schools. Pursuant to the joint program of the Ministry of Defence and the Ministry of Education and Science four scientific centres are being renovated in such a manner and the equipment for common use is being installed.

Lithuania is witnessing deep changes in the science and technologies policies and practices due to a series of evolutionary factors which began to occur since the 1990s. These changes entail business, universities and government: enterprises have undergone a new challenge caused by an increasing difficulty in technological updating due to both the increase of competitors in a globalised market, and to a high complexity and risks in the introduction of innovations. On the one hand universities and industry have begun to compete for the acquisition of funds, on the other hand government is faced with social requests and economic demands. Therefore, authorities have to select and monitor the few resources they can manage. It gives a view of implementation of first configuration of 'triple helix' model, where sphere of authorities dominates. On the other hand, the policy of Lithuanian government, especially after the confirmed conception of Lithuania's White Book on Science and Technology, stimulates direct cooperation between industry and academic institutions by establishing technology parks and business incubators, business information centres, Lithuanian innovations centre and five its' agencies. Public investment in research and development in the last decade, stimulation by taxes and customs policy, involving into sector funds and risk capital and constantly increasing grade of cooperation between authorities, industry and university allows to make a finding in 'triple helix' model creation with overlapping spheres in Lithuania. 


\section{Conclusions}

Development of high technologies is strategically important to the economic growth of EU and its' countries. However, as the high technology market statistics indicates, the development in this sector in Lithuania is not that dynamic. Many reasons for that are associated with the specific characteristics of high technologies: short life cycle, inseparability from science and technologies, as well as the existing infrastructure. Therefore, the high technology business is highly risky and investment consuming. It is also characterized by the constantly changing environment and intense competition in the market.

In solving the said problems of development of the high technologies market, the top priority is development of high technologies. The high technologies development is implementation of the 'triple helix' model covering integration of the public and private sector as well as science, where the public sector is trusted with strategic planning, organization and control of high technologies development, the science supported by the state and the private sector is responsible for creation of new high technologies and the business is provided with opportunities to implement new high technologies.

In general, 'triple helix' model indicates a relationship among the academic authorities, industry and authorities as a merger of overlapping areas reflecting an impact of each element on other spheres. There are three main the most common configurations of the 'triple helix' model: in the first model the areas indicating elements of the industry and academic public exist independently, without any interaction, and the dominant role of an intermediary is played by the authorities being the only element ensuring relations between the sectors; the second model shows interactive relations of different elements; the third model indicates close cooperation among separate institutions of science, business and government.

The most successful model for high technologies development is the third model of 'triple helix', which shows the highest degree of cooperation among authorities, industry and academic public as the configuration of 'triple helix' model allows solving all problems in implementation of innovations.

The analysis of Lithuanian high technologies market development indicates that the development of high technologies in Lithuania is also based on 'triple helix' model. However, not the most efficient configuration of 'triple helix' model is present here, since the dominant sphere of authorities is leading. Therefore, the priority for Lithuania for high technologies development should be turning to the 'triple helix' model, which guarantees the highest degree of cooperation among authorities, industry and academic public in order to have efficient strategic planning, organization and control of high technologies development, support by the state and the private sector for creation of new high technologies and creating opportunities for their implementation.

\section{References}

Agmon, T.; Messica, A. 2006. Optimal Public Sector Support for the high Technology Sector in the Presence of Dynamic Venture Capital Funding [online] [accessed 12 October 2008]. Available from Internet: <http://papers.ssrn. com/sol3/papers.cfm?abstract_id=878368 $>$.

Allen, J. C. 1992. Starting a Technology Business. London. $244 \mathrm{p}$.

Aydalot, P.; Keeble, D. 1988. High Technology Industry and Innovative Environments: The European Experience. London. $241 \mathrm{p}$.

Bielskis, A. A.; Dzemydiené, D.; Denisov, V.; Andziulis, A.; Drungilas, D. 2009. An approach of multi-agent control of bio-robots using intelligent recognition diagnosis of persons with moving disabilities, Technological and Economic Development of Economy 15(3): 377-394.

doi:10.3846/1392-8619.2009.15.377-394

Chabot, C. 2008. Defining High Technology [online] [accessed 12 October 2008]. Available from Internet: <http://www. parcogeneticasalute.it/risorse/biotech/Cluster\%20high\%20 tech $\% 20 \% 20 \mathrm{PMI} \% 20 \mathrm{e} \% 20$ innovazione/chabot.htm>.

Clarke, A.; Stough, R. R. 2001. Defining High Tech [online] [accessed 12 October 2008]. Available from Internet: $<$ http://www.cerc. com/images/customerfiles/DefiningHigh Tech.pdf $>$.

Davidow, W. H. 1986. Marketing High Technology: An Insider's View. New York. 224 p.

Etzkowitz, H.; Gulbrandsen, M.; Levitt, J. 2000. Public Venture Capital: Government Funding Sources for Technology Entrepreneurs. New York: Harcourt.

Gardner, D. M.; Johnson, F.; Lee, M.; Wilkinson, I. 2000. A contingency approach to marketing high technology products, European Journal of Marketing 9/10: 1053-1077. doi: $10.1108 / 03090560010342476$

Ghazinoory, S.; Ghazinouri, R. 2009. Nanotechnology and sociopolitical modernity in developing countries: case study of Iran, Technological and Economic Development of Economy 15 (3): 395-417. doi:10.3846/1392-8619.2009.15.395-417

Goldman, A. 1982. Short product life cycle: implications for marketing activities in small high-tech companies, $R$ and $D$ Management 12(2): 9-81.

doi:10.1111/j.1467-9310.1982.tb00487.x 
Goss, E.; Vozikis, G. S. 1994. High-tech manufacturing: firm size, industry and population density, Small Business Economics 6: 7-291. doi:10.1007/BF01108396

Kask, Ch.; Sieber, E. 2002. Productivity Growth in "high-tech" Manufacturing Industries [online] [accessed 12 October 2008]. Available from Internet: < http://www.bls.gov/opub/mlr/ 2002 /03/art2full.pdf $>$.

Lawrance, J.; Miller, S. 1996. Defining the British Columbia High Technology / knowledge sector in British Columbia [online] [accessed 12 October 2008]. Available from Internet: <http://www.bcstats.gov.bc.ca/data/bus_stat/busind/ hi_tech/ht_def.pdf $>$.

MacInnis, M.; Heslop, L. A. 1990. Marketing planning in high-tech environment, Industrial Marketing Management 19: 16-170.

McNally, K. 1995. External Equity Finance for High Technology-Based Firms in the UK: The Role of Corporate Venture Capital. Venture Finance Working Paper 13.

McIntyre, S. H. 1988. Marketing adaptation as a process in the product life cycle as radical innovations and high technology products, Journal of Product Innovation Management 19: 52-140.

McGuckin, R. H.; Abbott, T. A.; Herrick, P.; Norfolk, L. 1992. Measuring advanced-technology products trade: a new approach, Journal of Official Statistics 8(2): 223-233.

Meldrum, M. J. 1995. Marketing high-tech products: the emerging themes, European Journal of Marketing 10: 45 58. doi:10.1108/03090569510098492

Melnikas, B. 2004. Transformacijos. Vilnius. 749 p.

Rausch, L. M. 1998. High-tech Industries Drive Global Economic Activity [online] [accessed 12 October 2008]. Available from Internet: < http://www.nsf.gov/statistics/issuebrf/ sib98319. htm>.

Rexroad, R. A. 1983. High Technology Marketing Management. New York. 219 p.

Riggs, H. E. 1983. Managing High Technology Companies. Belmont, CA. 333 p.
Rosen, D. E.; Schroeder, J. E.; Purinton, E. F. 1998. Marketing High-Tech Products: Lessons in Customer Focus from the Marketplace [online] [accessed 12 October 2008]. Available from Internet: <http://www.amsreview.org/ articles/rosen06-1998.pdf>.

Rosenau, M. D. Jr. 1988. Speeding your product to market, Journal of Consumer Marketing 5: 23-33.

Rossi F. 2005. Innovation policy in the European Union: instruments and objectives, MPRA Paper [online] [accessed 12 October 2008]. Available from Internet: http://mpra. ub.uni-muenchen.de/2009/1/MPRA_paper_2009.pdf $>$.

Ryans, J. K.; Shanklin, W. L. 1984. Principles of high-technology marketing, Business Marketing September: 39-42.

Snitka, V. 2002. Moksliniu tyrimu, technologiju, inovaciju politika ir žiniu ekonomikos pletra. Kaunas: Naujasis lankas. $253 \mathrm{p}$.

Sahadev, S.; Jayachandran, S. 2004. Managing the distribution channels for high-technology products: a behavioural approach, European Journal of Marketing 1/2: 121-149. doi:10.1108/03090560410511159

Shanklin, W. L.; Ryans, J. K. 1984. Marketing High Technology. Lexington. $216 \mathrm{p}$.

Walsh, K. 2003. Foreign High-Tech R\&D in China [online] [accessed 12 October 2008]. Available from Internet: <http:// www.stimson. org/techtransfer/pdf/FinalReport.pdf $>$.

Wessner, C. 1999. The Advanced Technology Program: Challenges and Opportunities. Washington: National Academy Press.

Viale, R.; Campodall' Orto, S. 2000. Neocorporations or Evolutionary Triple Helix? Suggestions Coming from European Regions, in the Third Triple Helix Conference, 26-29 April 2000, Rio de Janeiro.

Žalioji knyga: Kaip pradèti aukštuju technologiju versla [Green paper] 2006 [online] [accessed 12 October 2008]. Available from Internet: <http://www.zef.lt/zef/modules/ document_publisher/documents/2/ZEF_zalia_aukstuju_ technologiju_verslas_060310.pdf $>$. 